\title{
Meiosis and fluorescent banding in Edessa meditabunda and E. rufomarginata (Heteroptera: Pentatomidae: Edessinae)
}

\author{
Pablo J. REBAGLIATI ${ }^{1 *}$, Alba G. PAPESCHI ${ }^{1,2}$ and Liliana M. MOLA ${ }^{1,2}$ \\ ${ }^{1}$ Laboratorio de Citogenética y Evolución, Departamento de Ecología, Genética y Evolución, Facultad de Ciencias Exactas y \\ Naturales, Universidad de Buenos Aires. Intendente Güiraldes y Costanera Norte, C1428-EHA Ciudad Universitaria, Ciudad \\ Autónoma de Buenos Aires, Argentina \\ ${ }^{2}$ Member of the Carrera del Investigador Científico (CONICET)
}

Key words. Heteroptera, Edessa, holokinetic chromosomes, fluorescent banding, meiosis

\begin{abstract}
Species of Pentatomidae are cytogenetically characterized by the presence of holokinetic chromosomes, a pre-reductional type of meiosis, and a great constancy not only in chromosome number ( $2 \mathrm{n}=14$ in $85 \%$ of the 250 species analyzed) but also in the sex chromosome determining system (XY/XX).

Edessa meditabunda and E. rufomarginata males have $2 \mathrm{n}=14=12+\mathrm{XY}$, and both species present small telomeric positively heteropycnotic bands which are DAPI and CMA bright. In E. meditabunda the NOR region is clearly revealed at the telomeric region of the largest autosomal pair by silver staining and CMA banding. Meiotic behaviour of both species follows the general pattern of the order: autosomes divide pre-reductionally, sex chromosomes are achiasmatic and divide postreductionally, and at both metaphase plates the autosomes become arranged in a circle with the sex chromosomes lying at its center. In E. meditabunda, however, the larger sex chromosome is generally observed at metaphase I forming part of the ring of autosomal bivalents. Bivalents with two chiasmata are frequently observed in E. meditabunda and E. mfomarginata; mean chiasma frequency $(6.45$ and 6.26 , respectively) differ significantly between both species, but differences between populations within each species are not significant.

The metaphase plate arrangement of autosomes and sex chromosomes is rather constant in Heteroptera. However, our results in $E$. meditabunda together with previous reports in other species of the order led us to suggest that the metaphase plate arrangement is more liable to variation at the first meiotic division than at the second one, when it is almost constant. The presence of ring bivalents in both species here analyzed constitutes further evidence against the previous statement of only one chiasma per bivalent in Heteroptera.
\end{abstract}

\section{INTRODUCTION}

Edessinae Amyot \& Serville, 1843, is a subfamily of Pentatomidae comprised of four genera: Edessa Fabricius, 1803 (259 described species), Olbia Stål, 1862 (5 species), Pantochlora Stål, 1870 (1 species), and Peromatus Amyot \& Serville, 1843 (7 species) (Fernandes \& van Doesburg, 2000). Edessa meditabunda (Fabricius, 1812) and E. rufomarginata (De Geer, 1773) are stink bugs very well known in Argentina because they are of great economic importance; both species feed on wild and cultivated plants, principally Solanaceae species. Immature and adults of these species have highly developed scent glands that produce irritating secretions to defend themselves against predators. Edessa meditabunda is distributed from northern Argentina to the Río Negro Valley, and $E$. rufomarginata was collected in some provinces of east and central Argentina (Bosq, 1937, 1940; Quintanilla et al., 1976; Rizzo, 1971, 1976; Saini, 1989, 1992).

One of the most important cytogenetic characteristics of the order Heteroptera is the holokinetic nature of its chromosomes, in contrast to the monocentric chromosomes (i.e., with a localized centromere) present in most organisms (Ueshima, 1979). Within the Pentatomidae 250 species belonging to six subfamilies have been cytogenetically analyzed, and a great constancy in chromosome number ( $2 n=14$ in $85 \%$ of the species) and the sex chromosome determining system (XY/XX in $99 \%$ of the species) has been reported (Dey \& Wangdi, 1988; Manna \& Deb-Mallick, 1981; Nuamah, 1982; Rebagliati, 2000; Rebagliati et al., 2001; Sathapathy \& Patnaik, 1988; Ueshima, 1979). The subfamily Edessinae is one of the less studied, 11 out of the 13 species cytogenetically analyzed belong to the genus Edessa, and all of them have $2 \mathrm{n}=14, \mathrm{n}=6+\mathrm{XY}$ (Table 1$)$.

In the present contribution, male karyotype, heterochromatin composition and distribution (DAPI-CMA banding), and meiotic behaviour of E. meditabunda and E. rufomarginata are described and compared; furthermore, the silver staining technique was applied to $E$. meditabunda in order to reveal the location of the nucleolus organizing region. Finally, chiasma frequency within and between the species is also analyzed.

\section{MATERIAL AND METHODS}

The present study was performed on adult males of $E$. meditabunda from Macomita (8 males) (Tucumán Province); Gilbert (4 males), Gualeguaychú (3 males), Almada (4 males), and Colón (4 males) (Entre Ríos Province); Hughes (1 male) (Santa $\mathrm{Fe}$ Province); and males of $E$. rufomarginata from Cuchilla de las Aguilas (12 males) (Benito Juárez, Buenos Aires

\footnotetext{
* Corresponding author. Fax: ++54 011 4576-3384; e-mail: gchu@bg.fcen.uba.ar
} 
TABLE 1. Male diploid and haploid chromosome numbers of species of Edessinae.

\begin{tabular}{lccl}
\hline Species & $2 \mathrm{n}$ & $\mathrm{n}$ & \multicolumn{1}{c}{ References } \\
\hline Brachystethus & 14 & $6+\mathrm{XY}$ & Schrader, 1946; 1960 \\
rubromaculatus & & & \\
Edessa caldaria & 14 & $6+\mathrm{XY}$ & Schrader, 1941a \\
E. celsa & 14 & $6+\mathrm{XY}$ & Schrader, 1941a \\
E. costalis & 14 & $6+\mathrm{XY}$ & Schrader, 1941a \\
E. fuscidorsata & 14 & $6+\mathrm{XY}$ & Schrader, 1941a \\
E. irrorata & 14 & $6+\mathrm{XY}$ & Schrader, 1941a \\
E. laticornis & 14 & $6+\mathrm{XY}$ & Schrader, 1941a \\
E. meditabunda & 14 & $6+\mathrm{XY}$ & This work \\
E. picticentris & 14 & $6+\mathrm{XY}$ & Schrader, 1941a \\
E. rufomarginata & 14 & $6+\mathrm{XY}$ & Schrader, 1941a; this work \\
E. vinula & 14 & $6+\mathrm{XY}$ & Schrader, 1941a \\
Edessa sp. 1 & 14 & $6+\mathrm{XY}$ & Schrader, 1941a \\
Edessa sp. 2 & 14 & $6+\mathrm{XY}$ & Schrader, 1941a \\
Peromatus notatus & 14 & $6+\mathrm{XY}$ & Schrader, 1941b \\
\hline
\end{tabular}

Province) from two different populations $500 \mathrm{~m}$ apart (B1 and B2).

The specimens were fixed in 3:1 absolute ethanol: glacial acetic acid; later, gonads were dissected out and kept in $70 \%$ ethanol at $4^{\circ} \mathrm{C}$. Slides were made by the squash method in iron propionic haematoxylin or acetic carmin. Fluorescent staining with the GC specific chromomycin A3 (CMA3) and AT specific 4'6-diamidino-2-phenylindole (DAPI) was performed on unstained slides. A piece of gonad was squashed in $45 \%$ acetic acid, the coverslip was then removed by the dry-ice method, and the slide was air-dried. Afterwards, the slides were incubated in methanol for 2 hs and then air-dried. One drop of a solution of $0.4 \mu \mathrm{g} / \mathrm{ml}$ DAPI in Mac Ilvaine's buffer $\mathrm{pH} 7(0.1 \mathrm{M}$ citric acid, $0.2 \mathrm{M} \mathrm{Na}_{2} \mathrm{HPO}_{4}$ ) was placed on each slide, covered with a coverslip, and incubated for $20 \mathrm{~min}$ at room temperature. The slides were then rinsed with distilled water, Mac Ilvaine's buffer and distilled water, and air-dried. Afterwards, one drop of a solution of $0.6 \mathrm{mg} / \mathrm{ml} \mathrm{CMA3}$ in Mac Ilvaine's buffer with $10 \mathrm{mM}$ $\mathrm{MgCl}_{2} \cdot 6 \mathrm{H}_{2} \mathrm{O}$ was placed on each slide, covered with a coverslip, and incubated for $1 \mathrm{hr}$ at room temperature. The slides were then rinsed with distilled water, Mac Ilvaine's buffer and distilled water, and air-dried. Slides were mounted in a drop of glycerol-Mac Ilvaine's buffer with $10 \mathrm{mM} \mathrm{MgCl}_{2} \cdot 6 \mathrm{H}_{2} \mathrm{O}$, and stored at $37^{\circ} \mathrm{C}$ for $72 \mathrm{hs}$ before microscopic analysis. The incubation and air-drying steps were performed in the dark. Fluorescence analysis was performed in a Leica Wild MPS52 fluorescence microscope with Leica appropriate filters.

The silver staining technique was performed on $E$. meditabunda slides as previously described (Papeschi, 1995).

Chiasma frequency of cells at diakinesis and metaphase I was compared by means of a three-level nested ANOVA (Sokal \& Rohlf, 1995).

\section{RESULTS}

\section{Meiotic analysis}

Spermatogonial cells of E. meditabunda show $2 \mathrm{n}=14$ $=12+\mathrm{XY}$ chromosomes without primary constrictions (holokinetic chromosomes) (Fig. 1A). At early meiotic prophase sex univalents $\mathrm{X}$ and $\mathrm{Y}$ are positively heteropycnotic. At pachytene they are frequently placed close to each other, and the nucleolus can be observed associated
Table 2. Number of chiasmata (q) and mean chiasma frequencies at diakinesis-metaphase I in specimens of Edessa meditabunda from Macomita (M) and Gilbert (G) and of $E$. rufomarginata from two samples from Benito Juárez (B1 and B2).

\begin{tabular}{|c|c|c|c|c|c|}
\hline \multirow[t]{2}{*}{ Individual } & \multicolumn{3}{|c|}{$\begin{array}{l}\text { Number of } \\
\text { cells with }\end{array}$} & \multirow[t]{2}{*}{ Total } & \multirow[t]{2}{*}{$\begin{array}{l}\text { Mean chiasma } \\
\text { frequency }\end{array}$} \\
\hline & $6 q$ & $7 \mathrm{q}$ & $8 \mathrm{q}$ & & \\
\hline \multicolumn{6}{|c|}{ E. meditabunda } \\
\hline M 1 & 28 & 16 & 4 & 48 & 6.5 \\
\hline M 2 & 31 & 15 & & 46 & 6.33 \\
\hline M 3 & 39 & 31 & 3 & 73 & 6.51 \\
\hline \multirow[t]{2}{*}{ M 4} & 26 & 12 & & 38 & 6,32 \\
\hline & & & & & $\bar{x} \pm \mathrm{SD}=6.43 \pm 0.039$ \\
\hline G 1 & 80 & 42 & 3 & 125 & 6.38 \\
\hline $\mathrm{G} 2$ & 14 & 10 & 1 & 25 & 6.48 \\
\hline G 3 & 43 & 31 & 3 & 77 & 6.48 \\
\hline \multirow[t]{2}{*}{ G 4} & 30 & 27 & 5 & 62 & 6.5 \\
\hline & & & & & $\bar{x} \pm \mathrm{SD}=6.46 \pm 0.034$ \\
\hline \multicolumn{6}{|c|}{ E. rufomarginata } \\
\hline B1 1 & 76 & 33 & & 109 & 6.3 \\
\hline B1 2 & 42 & 14 & & 56 & 6.25 \\
\hline B1 3 & 42 & 10 & & 52 & 6.19 \\
\hline \multirow[t]{2}{*}{ B1 4} & 75 & 31 & & 106 & 6.29 \\
\hline & & & & & $\bar{x} \pm \mathrm{SD}=6.27 \pm 0.025$ \\
\hline B2 1 & 77 & 23 & & 100 & 6.23 \\
\hline B2 2 & 56 & 17 & & 73 & 6.23 \\
\hline B2 3 & 34 & 12 & & 46 & 6.23 \\
\hline \multirow[t]{2}{*}{ B2 4} & 22 & 7 & & 29 & 6.24 \\
\hline & & & & & $\bar{x} \pm \mathrm{SD}=6.24 \pm 0.027$ \\
\hline
\end{tabular}

to the telomeric region of a large autosomal bivalent. At the diffuse stage, the autosomal bivalents decondense completely while the sex chromosomes continue associated and positively heteropycnotic (Fig. 1B). At diplotene the autosomes recondense, and their telomeric regions are slightly positively heteropycnotic. After late diplotene (Fig. 1C) and at diakinesis (Fig. 1D) the $\mathrm{X}$ and $\mathrm{Y}$ chromosomes become isopycnotic. From late diakinesis until anaphase II the larger sex chromosome continues isopycnotic with the autosomal bivalents while the smaller one is negatively heteropycnotic (Fig. 1E-J). At metaphase I the autosomal bivalents arrange in a circle with the sex univalents placed at different positions: both the $\mathrm{X}$ and the $\mathrm{Y}$ lying at the center of the ring (as is usual in Heteroptera) $(28 \%$, from a total of 110 cells) (Fig. 1F); or the smaller sex chromosome at the center of the ring and the larger forming part of it (72\%) (Fig. 1G). At anaphase I the autosomal bivalents divide reductionally and the sex univalents, equationally (Fig. 1H). During the second meiotic division, the metaphase II arrangement is always the same: the sex chromosomes associate end-to-end forming a pseudobivalent (touch-and-go pairing), and lie at the center of the ring of autosomes (Fig. 1I). At anaphase II the sex chromosomes $\mathrm{X}$ and $\mathrm{Y}$ segregate to opposite poles (post-reductional division) (Fig. 1J). No 


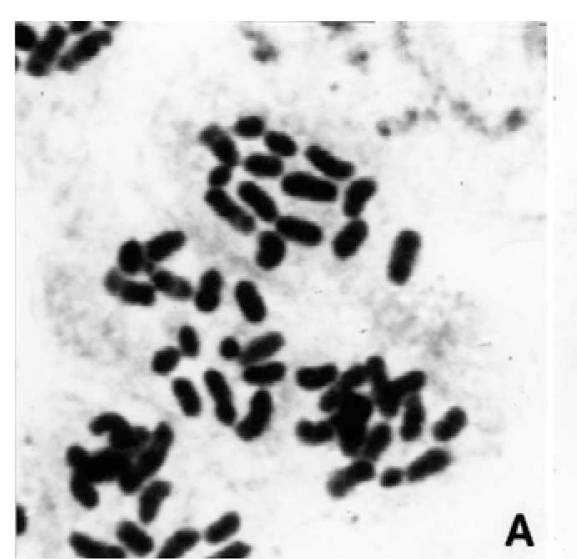

A
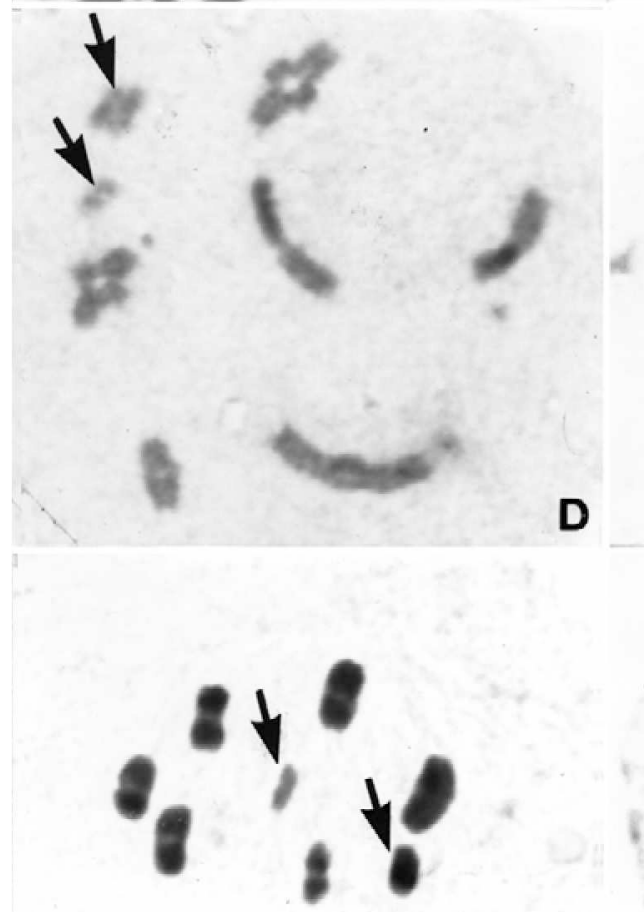

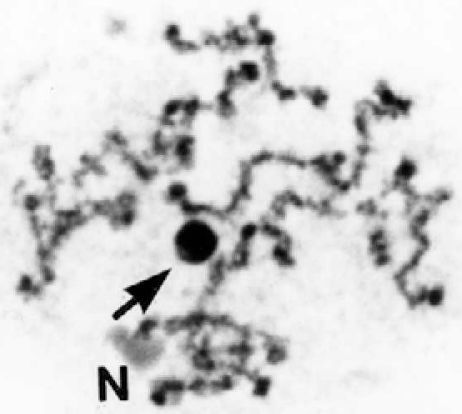

B
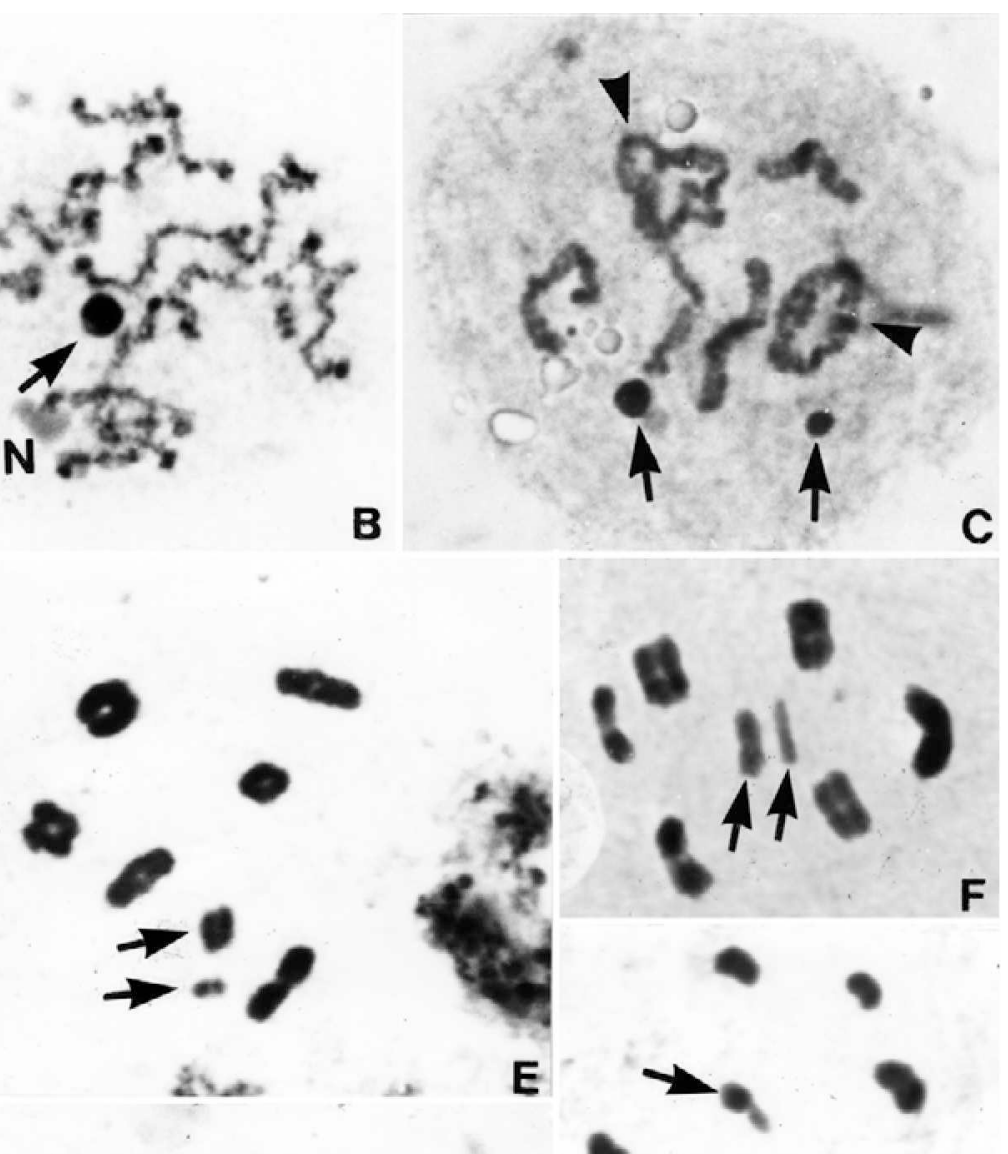

$\mathbf{F}$

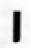

H

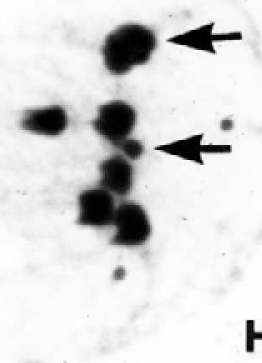

Fig. 1. Edessa meditabunda $(2 \mathrm{n}=14, \mathrm{n}=6+\mathrm{XY})$.

A - spermatogonial prometaphase; B - diffuse stage; C - early diakinesis; D - middle diakinesis; $\mathrm{E}$ - late diakinesis; $\mathrm{F}$ - metaphase I: both the $\mathrm{X}$ and the $\mathrm{Y}$ lie at the center of the ring of autosomal bivalents; $\mathrm{G}$ - metaphase I: the smaller sex chromosome lies at the center of the ring of the autosomal bivalents, while the larger one forms part of it; H - anaphase I; I - metaphase II: the XY pseudobivalent lies at the center of the ring of autosomes; $\mathbf{J}$ - anaphase II.

Arrowheads point to ring bivalents, arrows show sex chromosomes. $\mathrm{N}=$ nucleolus. $\mathrm{Bar}=10 \mu \mathrm{m}$.

differences in the meiotic behaviour have been detected among the individuals of $E$. meditabunda from different localities.

In spermatogonial cells of $E$. rufomarginata a diploid number of $14(2 \mathrm{n}=12+\mathrm{XY})$ is observed, and most chromosomes present positively heteropycnotic blocks at telomeric position (Fig. 2A-B). At pachytene, sex chromosomes are frequently associated and are positively heteropycnotic. During the diffuse stage, autosomal bivalents decondense while the $\mathrm{X}$ and $\mathrm{Y}$ continue associated and positively heteropycnotic (Fig. 2C). At diplotene the nucleolus can be observed associated to the telomeric region of an autosomal bivalent (Fig. 2D). From early prophase until this stage telomeric regions of autosomal bivalents are positively heteropycnotic (Fig. 2C-D). At diakinesis, sex chromosomes become isopycnotic and lie separated (Fig. 2E). At metaphase I autosomal bivalents arrange in a circle with the $\mathrm{X}$ and $\mathrm{Y}$ univalents at its center (Fig. 2F-G); the first meiotic division is reductional for the autosomes and equational for the sex chromosomes. At metaphase II the XY pseudobivalent lies at the center of the ring of autosomes (Fig. 2H).

In both $E$. meditabunda and $E$. rufomarginata, autosomes show a gradation of sizes, and the sex chromosomes are the smallest of the complement (Fig. 3). The X and $\mathrm{Y}$ chromosomes are unequal in size, and this differ- 


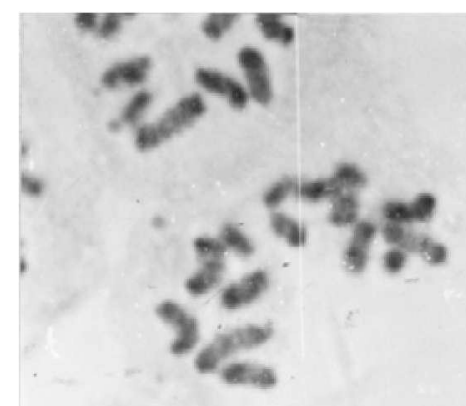

A
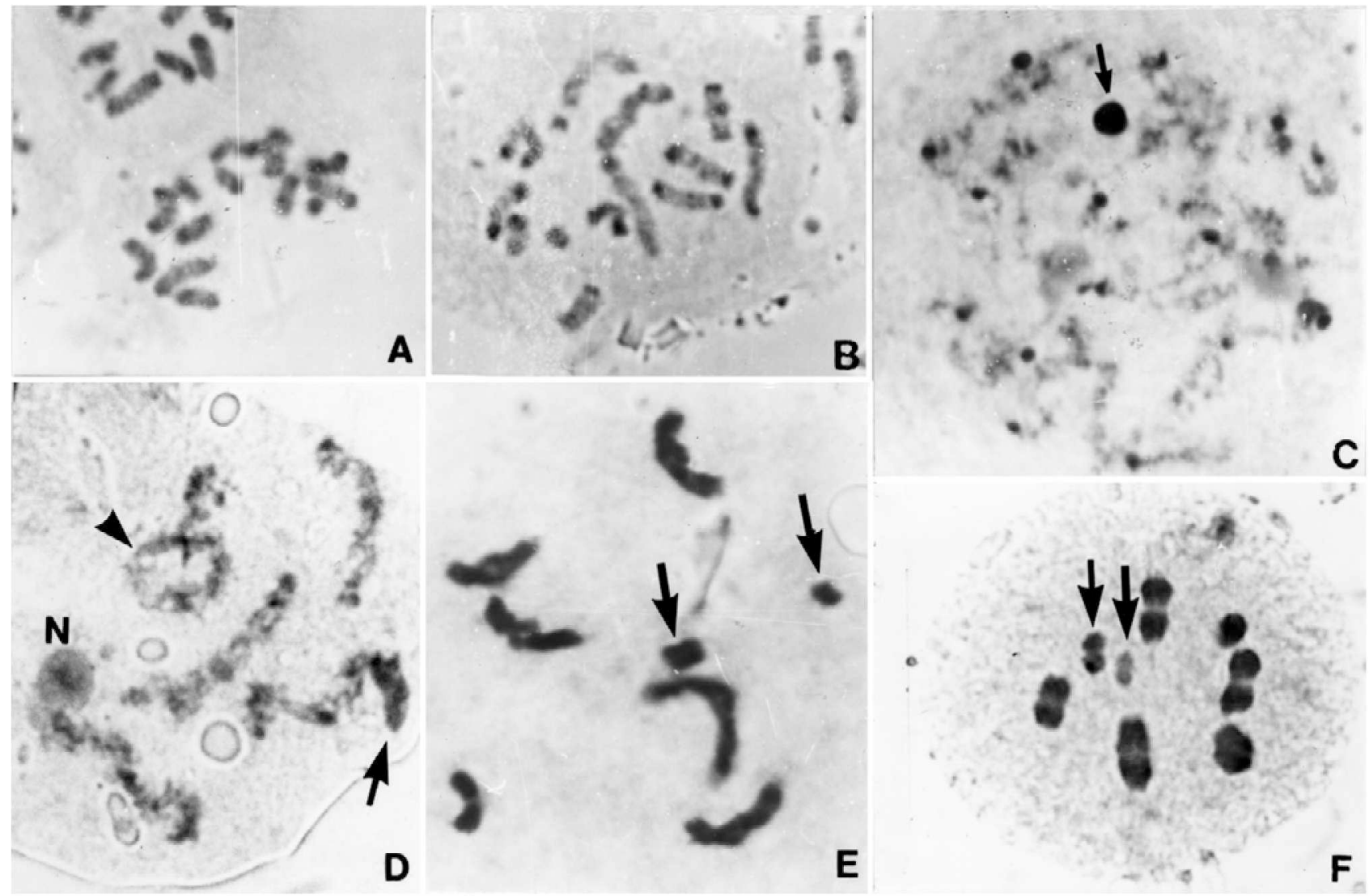

(1)
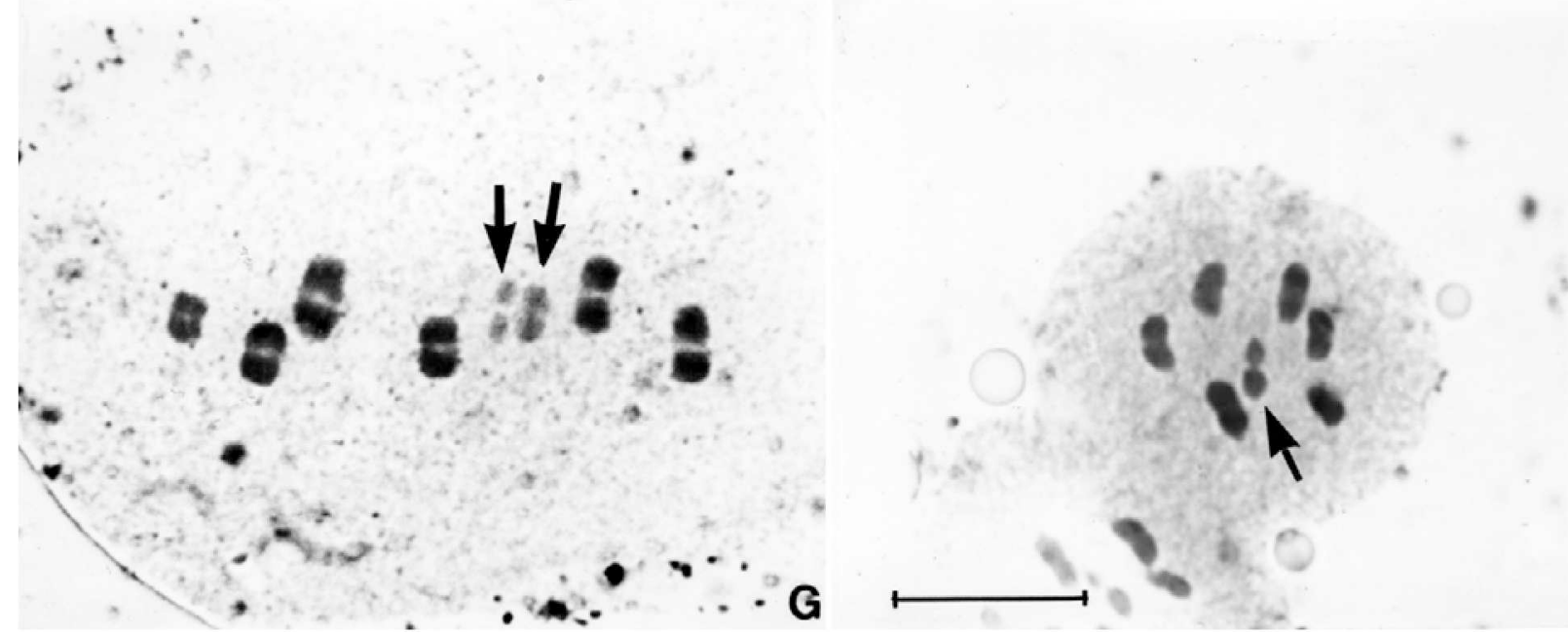

H

Fig. 2. Edessa rufomarginata $(2 \mathrm{n}=14, \mathrm{n}=6+\mathrm{XY})$

A-B - spermatogonial prometaphase; C - diffuse stage; D - diplotene; E - diakinesis; F-G - metaphase I: both the X and the Y univalents lie at the center of the ring of autosomal bivalents; $\mathrm{H}$ - metaphase II: the XY pseudobivalent lies at the center of the ring of autosomes.

Arrowheads point to ring bivalents, arrows show sex chromosomes. $\mathrm{N}=$ nucleolus. $\mathrm{Bar}=10 \mu \mathrm{m}$.

ence is more conspicuous in E. meditabunda than in $E$. rufomarginata.

In both species autosomal bivalents generally present only one chiasma (Fig. 1D, 2E); however, in some cells one ring bivalent (Fig. 1E, 2D) and up to two ring bivalents in E. meditabunda (Fig. 1C) have been observed. Chiasma frequency was analyzed in individuals of $E$. meditabunda from Macomita (Tucumán Province) $(\bar{x} \pm$ $\mathrm{SD}=6.43 \pm 0.039)$ and from Gilbert (Entre Ríos Province) $(\bar{x} \pm \mathrm{SD}=6.46 \pm 0.034)$; and in individuals of $E$. rufomarginata from two populations of Cuchilla de las Aguilas (Benito Juárez, Buenos Aires Province) $(\bar{x} \pm \mathrm{SD}$ $=6.27 \pm 0.025$ for $\mathrm{B} 1$ and $\bar{x} \pm \mathrm{SD}=6.24 \pm 0.027$ for $\mathrm{B} 2$ ) (Table 2). The analysis of mean chiasma frequency reveals that there are significant differences between $E$. meditabunda $(\bar{x} \pm \mathrm{SD}=6.45 \pm 0.026)$ and $E$. rufomarginata $(\bar{x} \pm \mathrm{SD}=6.26 \pm 0.018)(\mathrm{P}=0.0155)$, but the variability introduced by the populations within each species is not significant $(\mathrm{P}=0.6475)$ (Table 3 ). 
TABLE 3. Analysis of variance of mean chiasma frequency at diakinesis-metaphase $I$ in specimens of Edessa meditabunda and of E. rufomarginata.

\begin{tabular}{lcccc}
\hline Level & df & F & P & $\begin{array}{r}\text { VC } \\
(\%)\end{array}$ \\
\hline $\begin{array}{l}\text { Between species } \\
\begin{array}{l}\text { Between populations within } \\
\text { species }\end{array}\end{array}$ & 1 & 63.1003 & 0.0155 & $\sim$ \\
$\begin{array}{l}\text { Between individuals } \\
\text { within populations }\end{array}$ & 12 & 0.45 & 0.6475 & 0 \\
\begin{tabular}{l} 
Error (between cells) \\
\hline
\end{tabular} & 1049 & $\sim$ & $\sim$ & 99.44 \\
\hline
\end{tabular}

\section{Silver staining}

After silver staining of $E$. meditabunda the nucleolar cycle could be followed during meiosis (Fig. 4). At mitotic prometaphase two nucleoli are detected associated with the telomeric region of the largest autosomal pair (Fig. 4A). At early meiotic prophase only one nucleolus is generally observed, but at early diakinesis two nucleoli of different size can be detected associated to a pair of telo-

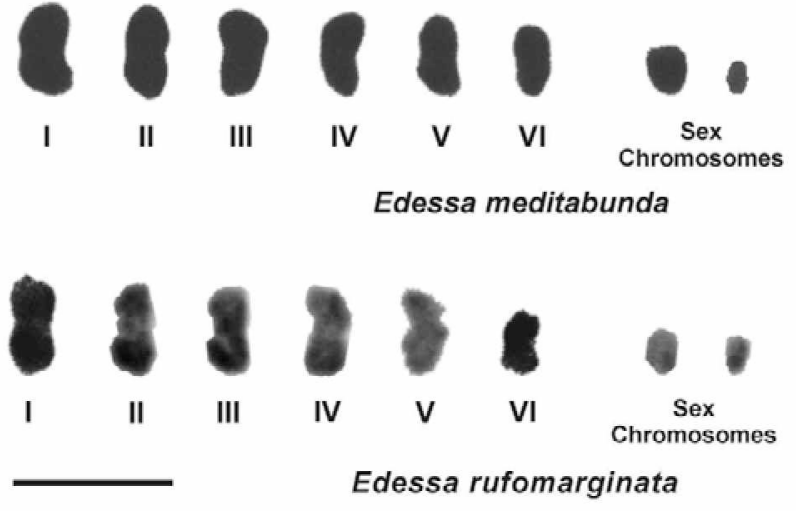

Fig. 3. Meiotic karyotypes of E. meditabunda and E. rufomarginata from cells at metaphase II. Bar $=5 \mu \mathrm{m}$.

meric regions of the largest autosomal bivalent (Fig. 4B-D).

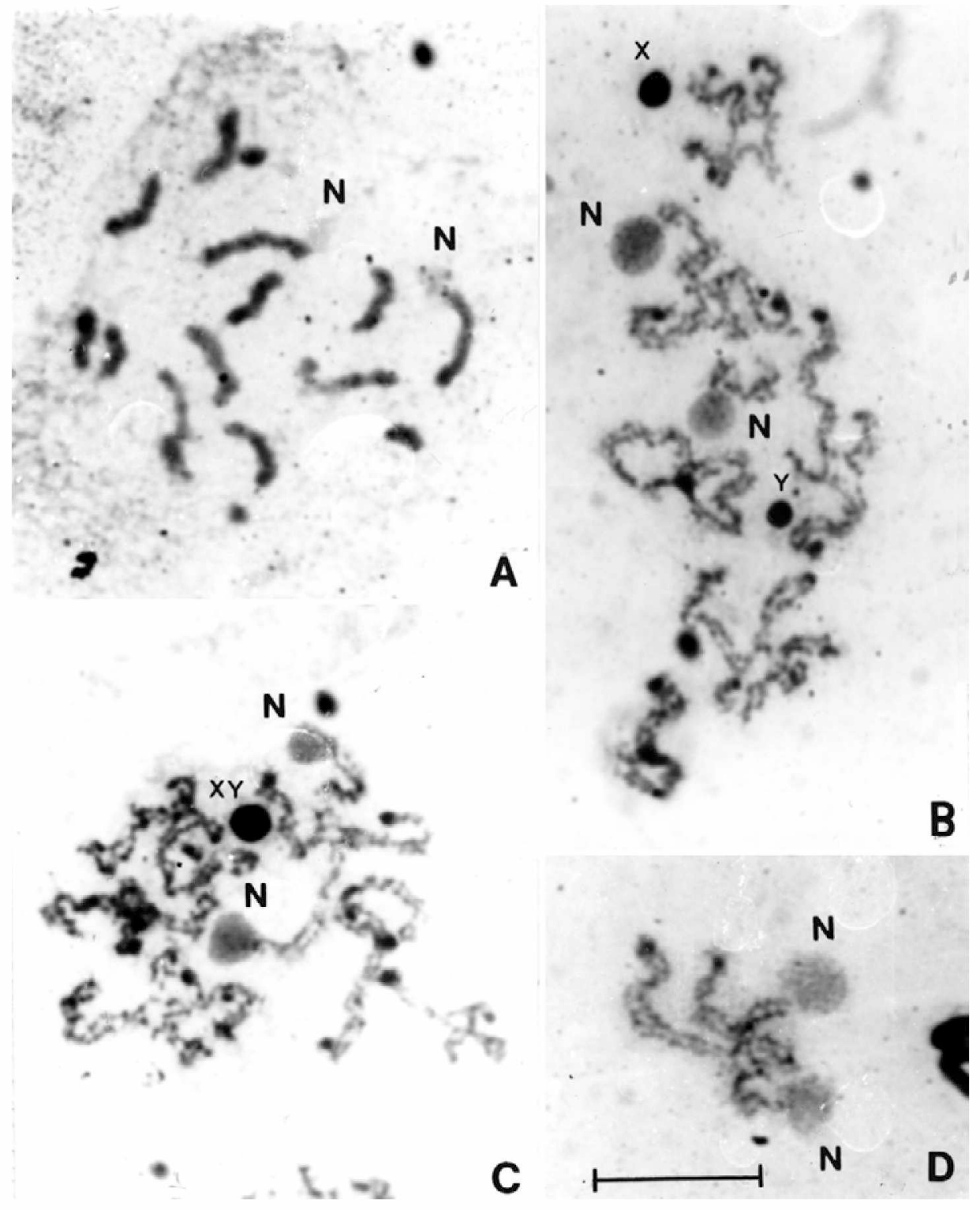

Fig. 4. Ag-staining in Edessa meditabunda.

A - Mitotic prometaphase; B-C - diplotene; sex chromosomes are separated in (B) and associated in (C); D - detail of NOR bivalent. Nucleoli are connected to the telomeric regions of the largest autosomal pair.

$\mathrm{N}=$ nucleolus. $\mathrm{Bar}=10 \mu \mathrm{m}$. 

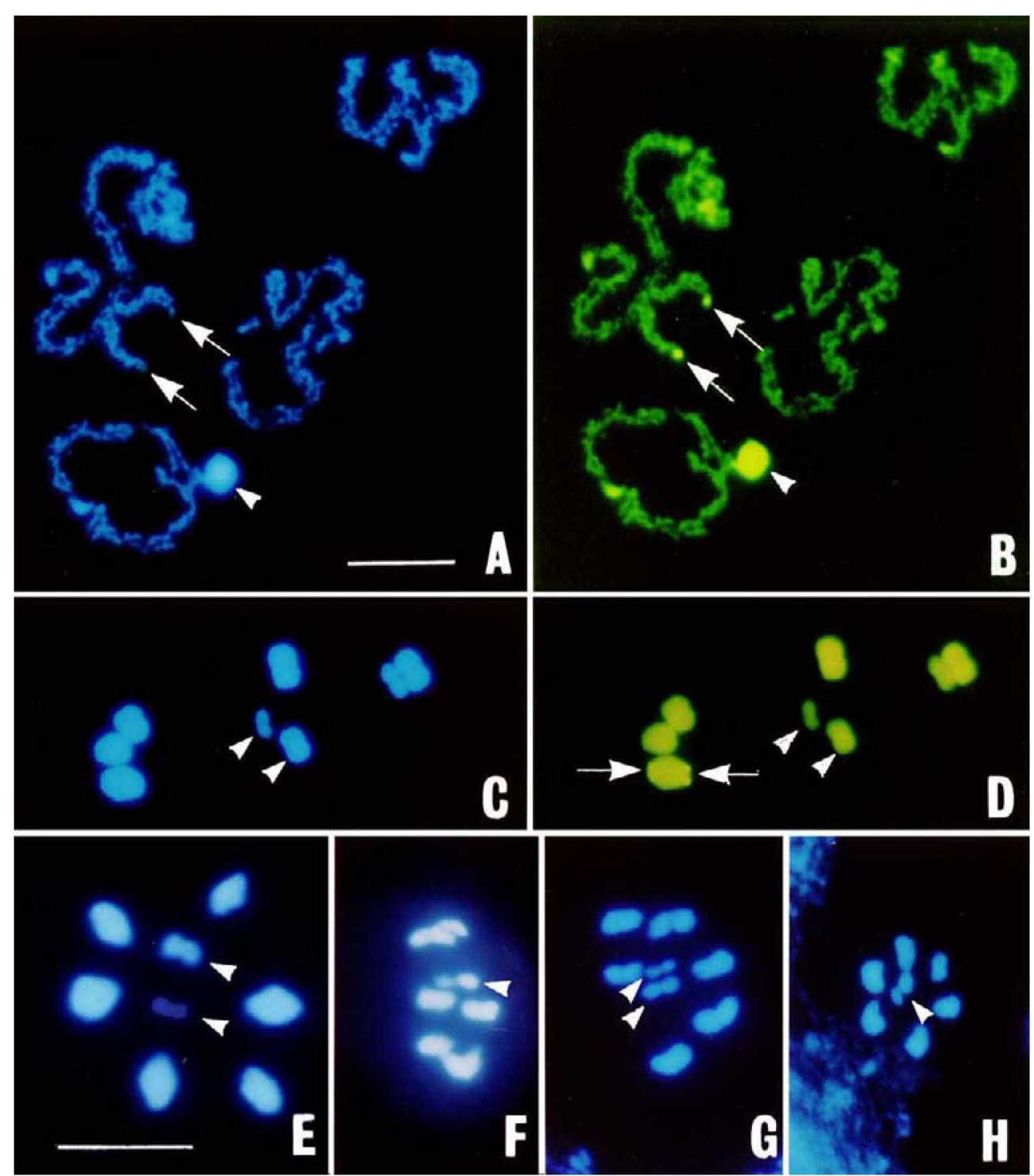

Fig. 5. DAPI (blue) and CMA (green) banding in E. meditabunda (A-F) and DAPI banding in E. rufomarginata (G-H). E. meditabunda: A-B - diplotene; C-E - metaphase I; F - metaphase II. E. rufomarginata: G - metaphase I; H - metaphase II.

Arrowheads point to sex chromosomes. Arrows in B-D show CMA bright band at the telomeric region of one large autosomal bivalent. Bar $=10 \mu \mathrm{m}$. All figures with the same magnification except $\mathrm{E}(\mathrm{Bar}=10 \mu \mathrm{m})$.

\section{DAPI and CMA banding}

DAPI and CMA banding in E. meditabunda reveals that sex chromosomes are DAPI bright and CMA bright during early prophase until diplotene (Fig. 5A-B). At metaphase I the smaller sex univalent is DAPI dull while the larger is as uniformly fluorescent as the autosomes (Fig. 5C, 5E). This difference continues until metaphase II (Fig. 5F). Autosomal bivalents show small DAPI bright and CMA bright bands at telomeric regions, while a conspicuous CMA bright and DAPI dull band is detected at a pair of telomeric regions of the largest autosomal pair (Fig. 5A, 5B, 5D). Similarly, in E. rufomarginata, sex chromosomes are DAPI bright during early meiotic prophase and the telomeric regions of autosomal bivalents are slightly DAPI bright and CMA bright. At both meiotic metaphases the larger sex chromosome is as DAPI and CMA bright as the autosomes, while the smaller one is as fluorescent with CMA as the autosomes but slightly less DAPI bright (Fig. 5G-H).

\section{DISCUSSION}

Within the subfamily Edessinae thirteen species have been cytogenetically analyzed, of which eleven belonged to the genus Edessa (Table 1). Edessa rufomarginata had been previously studied by Schrader (1941a), while the cytogenetics of $E$. meditabunda is described in the present paper for the first time.

In the order Heteroptera, chromosome arrangement at both meiotic metaphase plates is very specific and precise; although there are variations among different families, it is rather constant within each one (Ueshima, 1979). The most common pattern is the arrangement of 
autosomes in a circle with the sex chromosomes (either as univalents at metaphase I or associated in a pseudobivalent at metaphase II) lying at its center. Edessa rufomarginata follows this chromosome arrangement. On the other hand, some irregularities have been observed in metaphase I plates of E. meditabunda. The typical pattern is observed in some cells, but in most of them (72\%) the larger sex univalent forms part of the circle of autosomal bivalents while the smaller one lies at its center. Schrader (1941a) also described in E. irrorata that at metaphase I all chromosomes are arranged in a circle, but in many cells one or two chromosomes (not necessarily the sex univalents) lie at its center. This alteration of the regular pattern in E. meditabunda and E. irrorata, together with previous reports in species of Belostoma (Belostomatidae, Heteroptera) (Papeschi, 1992), give further support to the suggestion that the spatial arrangement of the different chromosome kinds is more liable to variation at metaphase I than at metaphase II, when it is almost invariable.

Bivalents with two chiasmata are frequently observed both in E. meditabunda and E. rufomarginata. The analysis of mean chiasma frequency reveals that in $50 \%$ of the cells of E. meditabunda and $25 \%$ of E. mufomarginata a ring bivalent is present. These results constitute additional evidence that support our suggestion that ring bivalents are not so rare in Heteroptera as earlier studies proposed (Rebagliati et al., 2001; Ueshima, 1979).

With reference to the heterochromatin content and distribution in Edessa species, Schrader (1941a) reported positively heteropycnotic telomeric regions in the autosomes of E. irrorata, E. costalis, and E. mufomarginata. In the present study, $E$. rufomarginata and $E$. meditabunda showed small telomeric positively heteropycnotic blocks that were DAPI bright and CMA bright until diakinesis. The telomeric localization of heterochromatin has already been described by $\mathrm{C}$ banding in many heteropteran species (Panzera et al., 1992, 1995; Papeschi, 1991); the bright fluorescence of these regions in E. meditabunda and E. rufomarginata both with DAPI (which reveals AT-rich DNA) and CMA (which enhances GC-rich DNA) could be explained if these regions were heterochromatin with interspersed AT and GC repeats. The conspicuous CMA bright band detected at the telomeric region of the largest autosomal bivalent in $E$. meditabunda together with the fact that the nucleolus, as revealed by silver staining, was associated with the telomeric region of this bivalent, led us to conclude that the NOR region is associated with a GC rich band. This correspondence between CMA positive banding and NOR regions has also been described in the $\mathrm{X}$ chromosome of aphids (Bizzaro et al., 1999; Mandrioli et al., 1999). In the present contribution the DAPI and CMA bright fluorescence of the sex chromosomes of $E$. meditabunda and E. rufomarginata until diplotene is consistent with the allocycly of these chromosomes during male meiosis, and it probably reflects different degrees of chromatin condensation rather than differences in base composition. From early prophase until diakinesis the $\mathrm{X}$ and $\mathrm{Y}$ chromosomes are both more condensed than the autosomes, while at this meiotic stage the autosomal bivalents and the larger sex chromosome are equally condensed. Conversely, the smaller sex chromosome is negatively heteropycnotic and less bright with the fluorescent dyes from metaphase I until the end of meiosis. The difference in fluorescence and pycnosis of the smaller sex chromosome could be due to a slight decondensation of this chromosome, or as a consequence of its small size and its strong stretching between the poles by the spindle fibers at the metaphase plates. On the other hand, differences in the pycnotic and fluorescent response of the smaller sex chromosome between $E$. meditabunda and $E$. rufomarginata could be explained by differences in the DNA content of these chromosomes.

ACKNOWLEDGEMENTS. The present study was performed with grants from the Buenos Aires University (UBA) (X212) and the National Research Council (CONICET) (PIP 4217) to Dr. L. Poggio and L. Mola, and from ANPCyT, PICT 01-08866 and Fundación Antorchas to Dr. A. Papeschi. The authors wish to thank Dr. Axel Bachmann for taxonomic identification of the specimens included in the study; Dr. A.P. Jaime and M.C. Lemme for material from Tucumán Province; Lic. S.G. Rodríguez Gil for collecting some specimens; and Lic. Beatriz González for her advice in statistical analysis.

\section{REFERENCES}

Bizzaro D., Barbolini E., Mandrioli M., Mazzoni E. \& MANICARDI G.C. 1999: Cytogenetic characterization of the holocentric chromosomes in the aphids Myzus varians and Myzus cerasi. Caryologia 52: 81-85.

Bose J. 1937: Lista preliminar de los hemípteros (Heterópteros) especialmente relacionados con la agricultura. Rev. Soc. Entomol. Argent. 9: 111-134.

Bose J. 1940: Lista preliminar de los hemípteros (Heterópteros) especialmente relacionados con la agricultura. Rev. Soc. Entomol. Argent. 10: 399-417.

DEY S.K. \& WANGDI T. 1988: Chromosome number and sex chromosome system in forty-four species of Heteroptera. Chromosome Inform. Serv. 45: 5-8.

Fernandes J.A.M. \& Van Doesburg P.H. 2000: The E. dolichocera-group of Edessa, Fabricius, 1803 (Heteroptera: Pentatomidae: Edessinae). Zool. Med. Leiden 73: 305-315.

Mandrioli M., Bizzaro D., Manicardi G.C., Gionghi D., BasSOLI L. \& BIANCHI U. 1999: Cytogenetic and molecular characterization of a highly repeated DNA sequence in the peach potato aphid Myzus persicae. Chromosoma 108: 436-442.

Manna G.K. \& Deb-Mallick S. 1981: Meiotic chromosomes constitution in forty-one species of Heteroptera. Chromosome Inform. Serv. 31: 9-11.

NUAMAH K.A. 1982: Karyotypes of some Ghanaian shield-bugs and the higher systematics of the Pentatomoidea (Hemiptera, Heteroptera). Insect Sci. Appl. 3: 9-28.

Panzera F., Alvarez A., Sanchez-Rufas J., Perez R., Suja J.A., Scyortzoff E., Dujardin J.P., Estramil E. \& Salvatella R. 1992: C-heterochromatin polymorphism in holocentric chromosomes of Triatoma infestans (Hemiptera: Reduviidae). Genome 35: 1068-1074.

Panzera F., Perez R., Panzera Y., Alvarez A., Scvortzoff E. \& Salvatella R. 1995: Karyotype evolution in holocentric chromosomes of three related species of triatomines (Hemiptera-Reduviidae). Chromosome Res. 3: 143-150.

PAPEschi A.G. 1991: DNA content and heterochromatin variation in species of Belostoma. Hereditas 115: 109-114. 
PAPeschi A.G. 1992: Estudios Citogenéticos y Evolutivos en Heteroptera. Tesis de Doctorado, Fac. Cs. Exactas y Naturales, Univ. Buenos Aires. vii-259 pp.

PAPESCHI A.G. 1995: Correspondence between C-banding and $\mathrm{Ag}-\mathrm{NOR}$ in the sex chromosomes of Belostoma oxyurum (Belostomatidae, Heteroptera). Cytologia (Tokyo) 60: 291-295.

Quintanilla R.H., Margheritis A.E. \& Rizzo H.F. 1976: Catálogo de hemípteros hallados en la provincia de Corrientes (Argentina). Rev. Soc. Entomol. Argent. 35: 115-133.

Rebagliati P.J. 2000: Estudios Citogenéticos en Especies Argentinas de Pentatomidae (Heteroptera). Tesis de Licenciatura, Fac. Cs. Exactas y Naturales, Univ. Buenos Aires, $70 \mathrm{pp}$.

Rebagliati P.J., Mola L.M. \& Papeschi A.G. 2001: Karyotype and meiotic behaviour of the holokinetic chromosomes of six Argentine species of Pentatomidae (Heteroptera). Caryologia 54: $339-347$.

Rizzo H.F. 1971: Aspectos morfológicos y biológicos de Edessa meditabunda (F) (Hemiptera, Pentatomidae). $1^{\circ}$ Congreso de Entomologia. Cuzco, Perú, pp.12-18.

Rizzo H.F. 1976: Hemípteros de Interés Agricola. Chinches PerJudiciales y Chinches Benéficas Para los Cultivos. Editorial Hemisferio Sur., 69 pp.
SAIN E.D. 1989: Clave para la identificación de las ninfas de pentatómidos encontrados en cultivos de soja. Rev. Soc. Entomol. Argent. 46: 129-139.

SAINI E.D. 1992: Pentatómidos (Heteroptera) encontrados sobre especies de Solanum. Rev. Soc. Entomol. Argent. 51: 63-70.

Satapathy S.N. \&. Patnaik S.C 1988: Chromosomal studies in seven species of family Pentatomidae (Heteroptera). Caryologia 41: 49-60.

SCHRADER F. 1941a: Heteropycnosis and non-homologous association of chromosomes in Edessa irrorata (Hemiptera, Heteroptera). J. Morph. 69: 587-604.

SCHRADER F. 1941b: Chromatin bridges and irregularity of mitotic coordination on the pentatomid Peromatus notatus Am. \& Serv. Biol. Bull. 81: 149-161.

SCHRADER F. 1946: The elimination of chromosomes in the meiotic division of Brachystethus rubromaculatus Dallas. Biol. Bull. 90: 19-31

SCHRADER F. 1960: Cytological and evolutionary implications of aberrant chromosome behaviour in the harlequin lobe of some Pentatomidae (Heteroptera). Chromosoma 11: 103-128.

SoKal R.R. \& RoHLf F.J. 1995: Biometry, 3rd ed. W.H. Freeman, New York, xviii-883 pp.

Ueshima N. 1979: Hemiptera II: Heteroptera. Animal Cytogenetics. Ed. B. John, Vol. 3, Insecta 6. Gebrüder Bornträger, Berlin.

Received May 2, 2002; revised October 31, 2002; accepted December 13, 2002 